\title{
The Image Of Lifestyle Change Through American Commercialism: A Study About Three Huge American Franchised Fast Food Restaurants
}

\author{
Setya Putri Rahayu ${ }^{1, *}$ \\ Universitas Aisyiyah Yogyakarta, West Ringroad 63 of Nogotirto Street Gamping Sleman 55292, Yogyakarta, Indonesia \\ setyaputri20@unisayogya.ac.id \\ * corresponding author \\ Submission date: 10 Juli 2018, Receipt date: 10 Oktober 2019, Publication date: 1 Juli 2020
}

\begin{abstract}
Human diet pattern changes year by year, from the Paleolithic diet done by the ancient human to the diet pattern of modern society. Hence, it changes from food gathering diet to the diet that mostly consist of high carbohydrates, high fat, high sodium, high sugar, and low fiber. The impact of diet change triggers the increase uncommunicable diseases such as hypertension, diabetes, and heart attack due to imbalance metabolism of the body. Health impact due to lifestyle changes cannot be separated from American commercialism as the center of western diet pattern of the most people nowadays. The objective of this study was to investigate the image of lifestyle change through American commercialism upon three huge fast food franchised restaurants namely Mc Donald's, KFC, and Pizza Hut. The research applied qualitative study with library research method to compare and contrast the information obtained from the reading process. The objects of the study were any information resources (books, journals, and websites) containing info about Mc Donald's, KFC, and Pizza Hut. Those huge franchise restaurants were chosen since their influence has massively spread around the world. The result of the study showed that life style changes upon people around the world cannot be separated from the impact of American commercialism of those three huge franchised restaurants.
\end{abstract}

Keywords: lifestyle, fast food, American commercialism

\section{INTRODUCTION}

Human diet changes day by day. It was started from the ancient human in food gathering and hunting period. The period is generally known as Paleolithic era. People in the era tended to enjoy raw vegetation and minimum-processed meats as their everyday diet menus. Then, people started to cultivate the land and develop agricultural method in order to provide them food. As time goes by, the way of processing food developed very significantly. People found abundant chemical substances to process, to color, to preserve, and to flavor the food in order to produce unlimited food creation.

On the other hand, people's activities become more complex. The society develops very rapidly. Modern people have completely different activities, actions, objectives, and accomplishments from those in the past period. The complexity of modern life requires a lot of things working quickly since they have abundant things to achieve. Modern people will not only think about what they eat today and how they sleep 
tonight. Running business, meeting people, discussing any scientific problem, preparing the best future,

and joining any affiliation are a little part of modern life. Modern people always demand everything to be ready as quick as possible because they will be left behind if they cannot accomplish what they need.

As a result, plenty manufacturer think hard to support the demand of modern people by creating a lot of innovations. One of those is how people can fulfill their need of food as fast and interestingly as possible. Food industry becomes one of never ending industries since it provides the most basic need of people necessity. The development of food industry is essential to change people lifestyle as well. Modern food manufacturers offer more variety both in the choice of the food and beverages and in how the food is served.

Notwithstanding, the growth of food industry in fact cannot be separated from American commercialism. American commercialism is the one which is blamed to bring the greatest influence of modern lifestyle. It is the started form the value of American free market as the foundation of economic freedom. The liberation of all aspects of human rights has brought immense impact to the whole of the world. Free market as the way of American commercialism emerges without any barrier. American products and brands have spread all over the world. American brands become the center of modern people lifestyle because it is perceived as popular culture or mass culture. Mass culture can be defined as the actions done by people which is widely favored or well-liked by many people (Storey, 1993). Furthermore, this mass culture further softens the spirit and intelligence by the ideological messages it transmits, shaped around values which emphasizes the benefit of materialism, glamour, and individualism (Edensor, 2002). The value of materialism and glamour concept triggers people to accept American products as the part of modern lifestyle.

Consequently, there are a lot of American products especially American franchised fast-food restaurants that become well-known around the world; some of those are KFC, Mc Donald's, and Pizza Hut. Those fast-food restaurants are the biggest franchised restaurants around the world. In 2016, Mc Donald's had been found in 120 countries around the world, and operated 36,899 restaurants worldwide and 168 restaurants around Indonesia (www.mcdonalds.co.id). Meanwhile, in the end of 2014, KFC had opened 18,875 outlets in 119 countries around the world. In Indonesia, it had established 540 stores in 133 Regencies/ Municipalities in Indonesia (www.kfcindonesia.com). Almost similarly, until 2017 Pizza Hut had established 16,796 restaurants in 97 countries worldwide, and it has opened more than 200 stores in 22 provinces in Indonesia (www.pizzahut.co.id). The huge growth rate of the restaurants shows that Indonesian people have been influenced by the trend of Americanization. The trend and the management of the restaurants also bring immense impact to food business and industry in Indonesia. Thousands of restaurants owners try to copy and adopt the concepts of good-looking outlets, attractive food and beverages, and delivery idea popularly brought by the American fast-food restaurants. Nowadays, people come to the restaurants not only to fulfill their hunger and complete their nutritional need but also to indicate their lifestyle and preference as the part of modern and popular society.

On the other hand, those restaurants serve food with high carbohydrate, high fat, high sodium, high sugar and less fiber such as burgers with thick buns, friend chicken and rice, bread with beef topping, ice cream, and soda. The availability of fruits and 
vegetable is very low compared to the carbohydrate and fats that the buyers consume. If people consume this kind of diet menu too often, it will disturb the metabolism of the body. Consequently, people will suffer from several diseases caused by imbalance body metabolism such as hypertension, diabetes, and heart attack. It is worsen by low mobility and movement of the body.

Hence, the study explains the image of lifestyle change through American commercialism that chose three huge franchised fast food restaurants as the objects of the study. Mc Donald's, Kentucky Fried Chicken, and Pizza Hut were chosen as the objects of the study since those were the pioneers of American fast food restaurants that have widely spread in Indonesia. The study covers historical background information of the fast food restaurants reaching Indonesia and comparison of nutritional contents of several menus served by the restaurants as well as the contrast between the nutritional fact and daily nutritional need of the people.

The objective of the study was to investigate the image of lifestyle change through American commercialism upon three huge fast food franchised restaurants namely $\mathrm{Mc}$ Donald's, KFC, and Pizza Hut, to analyze the nutritional facts among the menu served, and to contrast between nutritional content and daily nutritional need.

\section{RESEARCH METHODS}

The study applied descriptive qualitative method with library research as the approach. It begins with philosophical assumption, and it continued with data collection through books, journals, and websites. Then, data reduction as well as empirical data gathering was performed to gain cause-effect orientation and deterministic based on a priori theories. In the end, presentation in the form of data explanation and narration was conducted (Creswell, 2007).

The objects of the study were three giant American franchised fast food restaurants namely Mc Donald's, Kentucky Fried Chicken, and Pizza Hut. Those restaurants were chosen due to the widespread influence throughout Indonesian society. In addition, those restaurants belonged to American franchised company that had been brought to Indonesia more than 20 years ago. Main menus variety i.e. Mc Donald's with the burgers, KFC with the chicken and rice, and Pizza Hut with the bread with various topping also became significant consideration since comparison and contrast could be performed through the nutritional facts of among the food they served.

\section{American commercialism}

\section{RESULTS AND DISCUSSION}

Commercialism is understood as a way of life combining material privileged circumstances with as emphasis on symbolic meaning associated with shopping and possessions (Mitcham, 2005). Consumerism can be describe both in positive and in negative way. In positive point of view, it is perceived as a means of economic stimulation as well as shaping the identities and subcultures. On the other hand, it is alleged that consumerism is a manipulated and environmentally destructive habit leading to too many things being designed, produced, advertised, sold, and discarded (Rosenblatt, 1999 and World Watch Institute, 2004 in Mitcham, 2005). Furthermore, Goodwin (2008) explains that people are more than just consumers. Consumption activities most directly address living standard (of lifestyle goals. They do not merely fulfill their basic needs, but they also look for the pleasure through the use of the products and services. 
The United States is blamed to be the center of world consumerism. American products had spread widely around the world by bringing the value of high culture and popular lifestyle. America has become the symbol of consumerism (Strearns, 2001) since freedom of doing economic activities is highly valued without any limitation of the government's rule. People freely develop themselves especially in term of economic purposes in order to get the profit as highly as possible. The three economic freedom of the United States covers individual liberty to get personal gain or economic interest, the freedom of corporation to pursue maximum profits, and the freedom to enter markets and engage in business (Shaanan, 2010).

As the consequences, the producers do a lot of ways to boost their sale. One of which is by increasing the advertisement to invite consumers buying the products although they do not need them as well as by expanding their products overseas. Spreading American products all over the world completed with the propaganda that emphasizes on modernism invites people around the world regard that America becomes the center of the civilization as well as the values in which people try to follow in order to show their position in the society. People also consider that American cultures belong to high culture, so people try to copy how American people live, what they wear, and what they eat. People never realize that they are merely 'the victim' of American commercialism.

2. Fast food

What is fast food?

The term of fast food and junk food was still debatable among people. First of all let's understand what the contents of the food and beverages that people usually called as fast food or junk food. Fast food was the food that contained extremely high carbohydrates, high fats, high sugar, high salt, and low fiber, or what people understand as food with "empty calorie". Some soft drink contains only calories from sugar and no other nutrients, whereas cheeseburger might contain lots of fats, cholesterol, salt, and calories. If cheeseburger is classified as junk food, it is not because zero calories containing in each piece, rather the nutrients in every piece consist of great amount of unhealthy saturated fat and high salt (Albritton, 2009). Accordingly, what people assume as fast food or junk food is the food or drink which contains unfriendly nutrients to human body.

Ashakiran \& Deepthi (2012) mentioned several factors why fast food became very appealing to the consumers. Time factor, taste factor, attractiveness, and adversiting are significant things to attract people to keep consuming it. It is unquestionably that fast food is indeed ready to eat quickly with super delicious taste, and packed in a very attractive serving, and added with strong advertisement propaganda. Hence, people especially children and adolescents would purchase it without questioning what nutrients embodied in it.

Fast food and Lifestyle

As the development of postmodern society, what people eat is not only what they like and what they need. It shifts into the idea that what they eat shows what social status they belong.

Social media as the most leading influential devices in the disruptive era plays important role in spreading the value of high culture. Still, social media has arguably contributed to the broader promotion of fans, fans culture and fandom (Linden and Linden, 2017). 
People are longing to dine a particular restaurant just because of seeing their peers visiting that restaurant. When they are able to do the same thing, they are delighted because they have been considered to have similar class in the community. Thus, people follow the trend from the pictures or story uploaded by their peers, and they continue to spread their experience and information to other people again after feeling the experience.

In this case, people go to fast food restaurants is not only to eat their breakfast, lunch or dinner there but also to show that they follow the trend as what their peer do. Fast food and Health

Unfortunately, fast food restaurants that has become the trend of modern society do not serve complete nutrients for people's health. Food sold in the restaurants tend to be high in fat, energy dense, micronutrient-poor, and low in dietary fiber (Pimentel, et.al in Sanford, 2014). The typical nutrients containing in several fast food menus may lead to imbalance body metabolism.

The study compares the nutrition intake among three American franchised fast food restaurants namely Mc Donald's, KFC, and Pizza Hut. Then, the simulation menu in one meal will be converse, and in further it will be compare with the daily nutrition need by people. Table 1 shows the daily basis of nutrition need by people sorted by ages and sexes.

Table 1. Daily Nutrition Need

\begin{tabular}{cccc}
\hline Sex & Age (year) & Mild activities (in calorie) & Active (in calorie) \\
\hline Toddler & $3-\mathrm{Feb}$ & 1000 & $1000-1400$ \\
\hline Female & $8-\mathrm{Apr}$ & 1200 & $1400-1800$ \\
& $13-\mathrm{Sep}$ & 1600 & $1800-2200$ \\
& $14-18$ & 1800 & 2400 \\
& $19-30$ & 2000 & 2400 \\
& $31-50$ & 2000 & 2200 \\
& $51+$ & 1600 & $2000-2200$ \\
\hline Male & $8-\mathrm{Apr}$ & 1400 & $1600-2000$ \\
& $13-\mathrm{Sep}$ & 1800 & $2000-2600$ \\
& $14-18$ & 2200 & $2800-3200$ \\
& $19-30$ & 2400 & 3000 \\
& $31-50$ & 2200 & $2800-3000$ \\
& $51+$ & 2000 & $2400-2800$ \\
\hline
\end{tabular}

*Data source: www.klikdokter.com

Based on the table above, the mean of nutritional need is $2000 \mathrm{kkal}$ in teenagers and adults. 2000kkal is also used as a fundamental value in any information of nutritional facts. Hence, the study also uses $2000 \mathrm{kkal} /$ day as the foundation to measure the value of total calories that people need regardless the age and sexes of the people.

Table 2 explains about the value of nutrition in some menus served by Mc Donald's restaurants.

Table 2. Example of Mc Donald's Menus

\begin{tabular}{ccl}
\hline No & \multicolumn{1}{c}{ Menus } & \multicolumn{1}{c}{ Nutritional facts } \\
\hline 1. & Bacon Smokehouse Burger & Total calories: 840
\end{tabular}




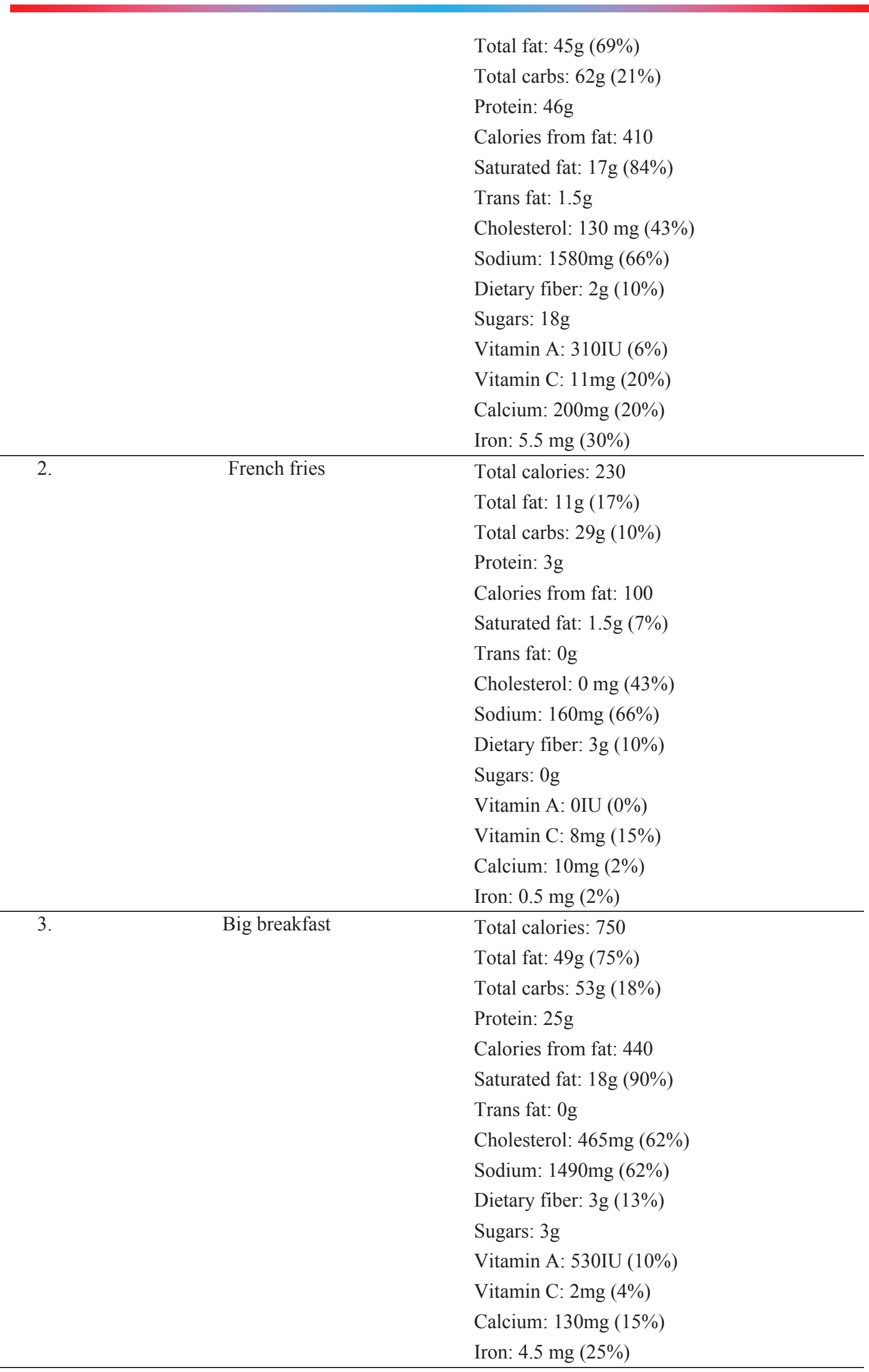




\begin{tabular}{|c|c|c|}
\hline \multirow[t]{15}{*}{4.} & Vanilla Cone Ice Cream & Total calories: 200 \\
\hline & & Total fat: $5 \mathrm{~g}(8 \%)$ \\
\hline & & Total carbs: $32 \mathrm{~g}(11 \%)$ \\
\hline & & Protein: $5 \mathrm{~g}$ \\
\hline & & Calories from fat: 45 \\
\hline & & Saturated fat: $3.5 \mathrm{~g}(16 \%)$ \\
\hline & & Trans fat: $0 \mathrm{~g}$ \\
\hline & & Cholesterol: 20 mg (7\%) \\
\hline & & Sodium: 80mg (3\%) \\
\hline & & Dietary fiber: $0 \mathrm{~g}(0 \%)$ \\
\hline & & Sugars: $24 \mathrm{~g}$ \\
\hline & & Vitamin A: 440IU (8\%) \\
\hline & & Vitamin C: $0 \mathrm{mg}(0 \%)$ \\
\hline & & Calcium: 170mg (15\%) \\
\hline & & Iron: $0 \mathrm{mg}(2 \%)$ \\
\hline & Coca cola & Total calories: 150 \\
\hline & & Total fat: $0 g(0 \%)$ \\
\hline & & Total carbs: $40 \mathrm{~g}(13 \%)$ \\
\hline & & Protein: $0 \mathrm{~g}$ \\
\hline & & Calories from fat: 0 \\
\hline & & Saturated fat: $0 \mathrm{~g}(0 \%)$ \\
\hline & & Trans fat: $0 \mathrm{~g}$ \\
\hline & & Cholesterol: $0 \mathrm{mg}(0 \%)$ \\
\hline & & Sodium: 35mg (1\%) \\
\hline & & Dietary fiber: $0 \mathrm{~g}(0 \%)$ \\
\hline & & Sugars: $40 \mathrm{~g}$ \\
\hline & & Vitamin A: 0IU (0\%) \\
\hline & & Vitamin C: $0 \mathrm{mg}(0 \%)$ \\
\hline & & Calcium: $0 \mathrm{mg}(0 \%)$ \\
\hline & & Iron: $0 \mathrm{mg}(0 \%)$ \\
\hline
\end{tabular}

*Percent of daily value based on 2,000 calories diet

Data source: www.mcdonalds.com

Based on the information related to nutrition containing in some Mc Donald's menu, an example of menu simulation can be analyzed. The example of the menu ordered by a consumer consisted of Bacon Smokehouse Burger and French Fries as the main menu. Then, the consumer also ordered Coca Cola as the drink and ice cream as the desert.

According to the table, the calories value can be counted as seen in Table 3

Table 3. Simulation of Mc Donald's menu

\begin{tabular}{ccc}
\hline No & Food and Drink & Calories (kkal) \\
\hline 1 & Bacon Smoke House Burger & 840 \\
2 & French fries & 230
\end{tabular}




\begin{tabular}{ccc}
3 & Coca cola & 150 \\
4 & Vanilla Cone Ice Cream & 200 \\
\hline & Total calories & $\mathbf{1 , 4 2 0}$ \\
\hline
\end{tabular}

By analyzing the number of calories in one meal in any Mc Donald's restaurants, the fulfillment of the calories has accommodated more than a half need of daily basis. If people eat three times a day, the calories fulfillment has exceeded the daily need. As a result, the excess of calories will be saved in the form of fat.

The next menu simulation will use KFC's menus as the example. Table 4 shows the examples of KFC menus.

Table 4. Example of KFC menus

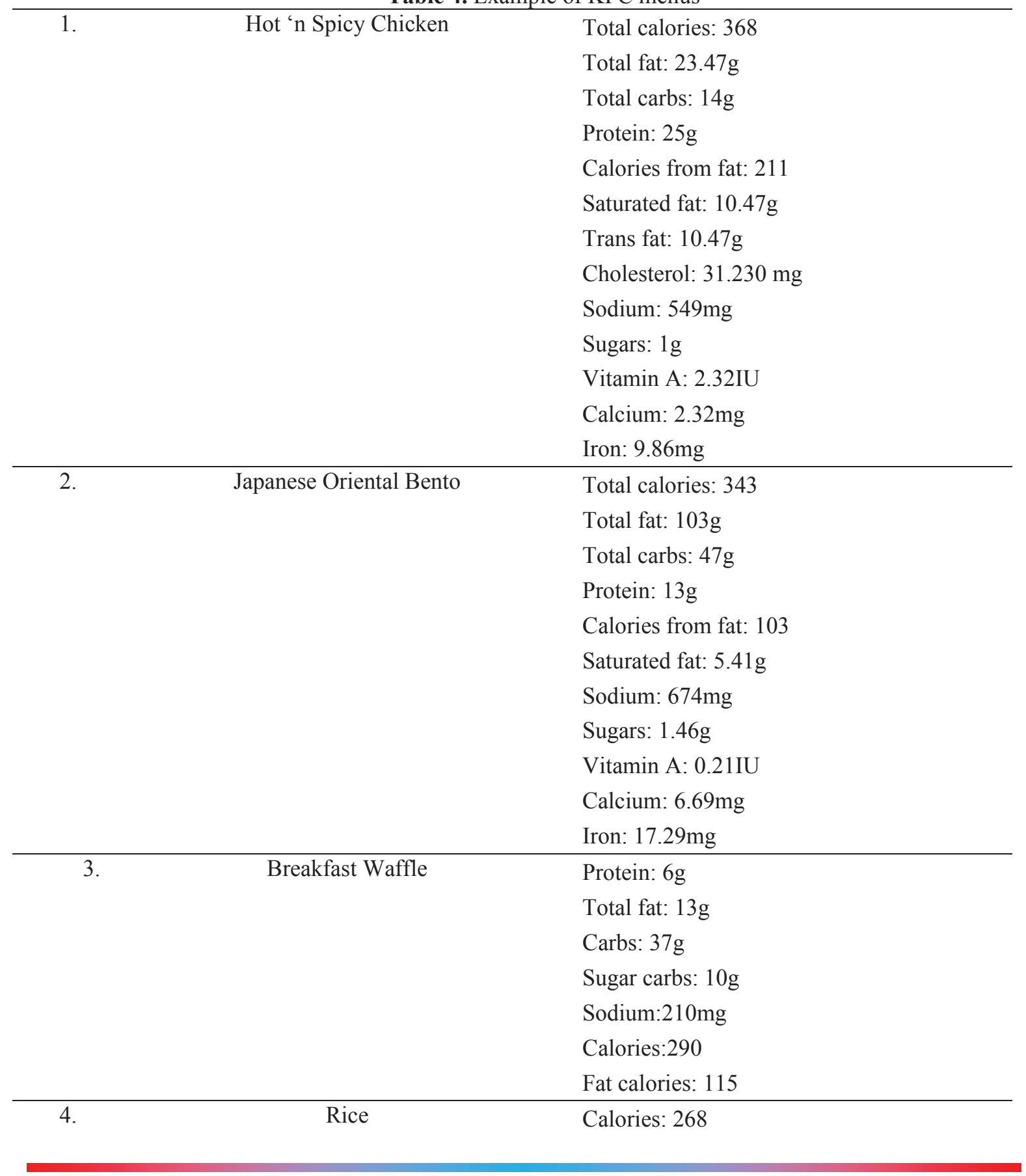




\begin{tabular}{ll} 
& Calories from fat: 2.7 \\
& Protein: $6.8 \mathrm{~g}$ \\
& Total Fat: $0.3 \mathrm{~g}$ \\
& Carbs: $60 \mathrm{~g}$ \\
& Sugar: $1.3 \mathrm{~g}$ \\
& Sodium: $27 \mathrm{mg}$ \\
& Calcium: $0.04 \%$ \\
\hline Pepsi Cola & Carbs: $32 \mathrm{~g}$ \\
& Calories: 130 \\
\hline
\end{tabular}

*Data source: www.kfcku.com

If a consumer bought 1 piece of friend chicken, one portion of rice, a glass of Pepsi cola, and ice cream as the dessert, he/she would probably have this following calories.

Table 5. Simulation of KFC's Menus

\begin{tabular}{ccc}
\hline No & Food and Drink & Calories (kkal) \\
\hline 1 & Hot n Spicy Chicken & 368 \\
2 & Rice & 268 \\
3 & Pepsi cola & 130 \\
4 & Vanilla Cone Ice Cream & 200 \\
\hline & Total calories & $\mathbf{9 6 6}$ \\
\hline
\end{tabular}

Total calories of 966kkal would remain steady if the consumer did not eat other additional snack. However, the simple KFC's menu still contain almost a half of daily need of calories. Nevertheless, the food that the consumer ate did not provide complete nutrients for body since it mainly consisted of fat and carbs.

The next simulation will use Pizza Hut's menu as the example. Table 6 presents the example of Pizza Hut menus and their calories.

Table 6. Example of Pizza Hut's menus

\begin{tabular}{ll}
\hline Garlic bread/piece & Calories: 140 \\
& Calories from fat: 70 \\
& Total fat: $8 \mathrm{~g}(12 \%)$ \\
& Saturated fat: $2 \mathrm{~g}(10 \%)$ \\
& Cholesterol: $0 \mathrm{mg}(0 \%)$ \\
& Sodium: $240 \mathrm{mg}(10 \%)$ \\
& Total carbs: $15 \mathrm{~g}(5 \%)$ \\
& Dietary fiber: $0 \mathrm{~g}(0 \%)$ \\
& Sugars: $0 \mathrm{~g}$ \\
& Protein: $3 \mathrm{~g}$ \\
\hline 2 & Calories: 210 \\
& Calories from fat: 110 \\
& Total fat: $12 \mathrm{~g}(18 \%)$ \\
& Saturated fat: $4.5 \mathrm{~g}(23 \%)$
\end{tabular}




\begin{tabular}{|c|c|c|}
\hline & & Cholesterol: $25 \mathrm{mg}(8 \%)$ \\
\hline & & Sodium: $470 \mathrm{mg}(20 \%)$ \\
\hline & & Total carbs: $17 \mathrm{~g}(6 \%)$ \\
\hline & & Dietary fiber: $\lg (4 \%)$ \\
\hline & & Sugars: $2 g$ \\
\hline & & Protein: $8 \mathrm{~g}$ \\
\hline \multirow[t]{10}{*}{3} & Supreme Stuffed Crust Pizza/piece & Calories: 360 \\
\hline & & Calories from fat: 160 \\
\hline & & Total fat: $18 \mathrm{~g}(28 \%)$ \\
\hline & & Saturated fat: $8 \mathrm{~g}(40 \%)$ \\
\hline & & Cholesterol: 45mg (15\%) \\
\hline & & Sodium: 780mg (33\%) \\
\hline & & Total carbs: $36 \mathrm{~g}(12 \%)$ \\
\hline & & Dietary fiber: $3 g(12 \%)$ \\
\hline & & Sugars: $2 g$ \\
\hline & & Protein: $15 \mathrm{~g}$ \\
\hline \multirow[t]{10}{*}{4} & Chicken Alfredo Pasta & Calories: 890 \\
\hline & & Calories from fat: 440 \\
\hline & & Total fat: $49 \mathrm{~g}(75 \%)$ \\
\hline & & Saturated fat: $14 \mathrm{~g}(70 \%)$ \\
\hline & & Cholesterol: 85mg (28\%) \\
\hline & & Sodium: $1620 \mathrm{mg}(68 \%)$ \\
\hline & & Total carbs: $74 \mathrm{~g}(25 \%)$ \\
\hline & & Dietary fiber: $6 \mathrm{~g}(24 \%)$ \\
\hline & & Sugars: $6 g$ \\
\hline & & Protein: $38 \mathrm{~g}$ \\
\hline \multirow[t]{10}{*}{5} & Fried Apple Pie (Desserts) & Calories: 440 \\
\hline & & Calories from fat: 90 \\
\hline & & Total fat: $10 \mathrm{~g}(15 \%)$ \\
\hline & & Saturated fat: $3.5 \mathrm{~g}(18 \%)$ \\
\hline & & Cholesterol: $5 \mathrm{mg}(2 \%)$ \\
\hline & & Sodium: $250 \mathrm{mg}(10 \%)$ \\
\hline & & Total carbs: $85 \mathrm{~g}(28 \%)$ \\
\hline & & Dietary fiber: $\lg (4 \%)$ \\
\hline & & Sugars: $59 \mathrm{~g}$ \\
\hline & & Protein: $2 \mathrm{~g}$ \\
\hline
\end{tabular}

*Data Source: Nutritonix.com

The simulation below will include two slices of garlic bread as the appetizer, one slice of Meat Lover's Pizza and a slice of Supreme Stuffed Crust Pizza as the main course, Fried Apple pie as the dessert, and cola as the beverage.

Table 7. The simulation is explained

\begin{tabular}{ccc}
\hline No & Food and Drink & Calories (kkal) \\
\hline 1 & Garlic bread (2 slices) & 280 \\
\end{tabular}




\begin{tabular}{ccc}
2 & Meat Lover's Pizza (1) & 210 \\
3 & Supreme stuffed crust pizza (1) & 360 \\
4 & Fried apple pie & 440 \\
5 & Cola & 130 \\
\hline & Total calories & $\mathbf{1 , 4 2 0}$ \\
\hline
\end{tabular}

The example of Pizza Hut's menus also showed that once the customer purchased in Pizza Hut, the fulfillment of the calories had exceeded more than half need of daily calories need.

Unfortunately, although some official restaurant's websites provide nutritional facts of their menus, most customers in fast food restaurants did not really care about the nutritional facts of the menus that they ordered since the restaurants did not explicitly provide the nutritional facts in every menu they sold. Actually, consumers were able to know the nutritional facts in the provided websites, but only few of them care about that.

Moreover, based on Table 2, Table 4, and Table 6, it is known that the nutrition in fast food did not able to accommodate the need of some significant minerals needed by human body. Most nutrients in fast food were fats, cholesterol, sodium, and carbohydrates. The availability of some kinds of vitamin, minerals and other nutrient components could not be provided in fast food menus. However, adequate mineral intake is important throughout the entire life especially for normal growth, immune function, and preventing chronic diseases in adulthood (Cabrera-Vique in Sanford, 2017). If people could not provide minerals and vitamins to the body, body metabolism would be severely disturbed.

Fat and sugar in combination are able to produce a dopamine-driven surge of intense pleasure in people leading to additive behavior (Ashakiran \& Deepthi, 2012). However, it must be noted that high fat and cabs content particularly cholesterol, sugar, and salt will lead to obesity, hypertension, diabetes, stroke, and heart attack in a chain.

Studies reveal that fast food cause several health problems i.e. beginning of clogging of arteries as early as at the age of 30, risks of prostate and breast cancer linked to the eating habits at puberty, setting of hypertension and osteoporosis at an early age, and vulnerability to slow growth, tooth damage, and obesity (Jackson and Anderson, in Ashkiran \& Deepthi, 2012).

\section{CONCLUSION}

How people eat nowadays is not merely what they need to fulfill the hunger as well as the nutrition need for the body. It is more to follow the trends that mainly brought by American commercials as well as to show the social status the people belong to.

American consumerism play significant impact to shift people's lifestyle especially the food consumption pattern. Fast food becomes a part of popular culture since it offers particular magnetisms to people namely fast, tasty, beautiful, and popular.

Based on the nutrition facts embodied in the examples of three American franchised fast food namely Mc Donald's, KFC, and Pizza Hut, it can be concluded that the menus offered by the restaurants do not contain complete nutrition for people's body. 
Excessive fats, carbs, cholesterols, and sodium may disturb the body metabolism to lead some health problem such as hypertension, diabetes, heart attack and obesity.

\section{REFERENCES}

Albritton, Robert. 2009. Let Them Eat Junk, How Capitalism Creates Hunger and Obesity. Pluto Press: New York

Ashakiran \& Deepthi R. 2012. Fast Food and Their Impact on Health. JKIMSU, Vol. 1, No. 2, July-Dec

Creswell, John W. 2007. Qualitative Inquiry and Research Design Choosing Among Five Approaches. SAGE Publications: University of Nebraska, Lincoln

Goodwin, Neva et. el. 2008. Consumption and the Consumer Society. GDAE Institute: Medford

Edensor, Tim. 2002. National Identity, Popular Culture, and Everyday Life. Berg Publishers.

Linden, Henrik and Sara Linden. 2017. Fans and Fan Cultures, Tourism, Consumerism, and Social Media. Palgrave Macmillan: USA

Mitcham, Carl. 2005. Encyclopedia of Science, Technology, and Ethics. Macmillan: USA

Sanford, Marlin G. 2014. Fast Foods: Consumption Patterns, Role of Globalization and Health Effect. Novinka: New York

Shaanan, Joseph. 2010. Economic Freedom and the American Dream. Palgrave Macmillan.

Strearns, Peter. 2001. Consumerism in World History, the Global Transformation of Desire. Routledge: London \& New York 